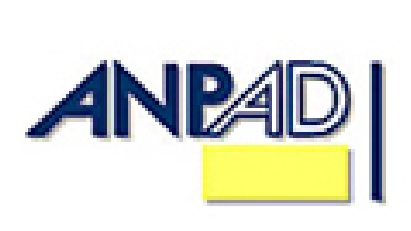

Disponível em

http://www.anpad.org.br/rac

RAC, Rio de Janeiro, v. 16, n. 2, art. 8, pp. 308-326, Mar./Abr. 2012

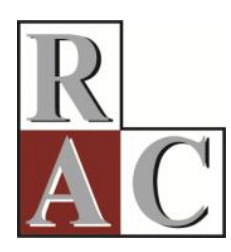

\title{
Executive MBA Programs: What Do Students Perceive as Value for their Practices?
}

\author{
Ana Claudia Souza Vazquez * \\ E-mail: acsvazquez@terra.com.br \\ Universidade Federal do Rio Grande do Sul - EA/PPGA/UFRGS \\ Porto Alegre, RS, Brasil. \\ Roberto Lima Ruas \\ E-mail: rlruas@ea.ufrgs.br \\ Universidade Federal do Rio Grande do Sul - EA/PPGA/UFRGS \\ Porto Alegre, RS, Brasil.
}

* Endereço: Ana Claudia Souza Vazquez

Rua Vicente da Fontoura, 2570/201, Porto Alegre/RS, 90640-002.

Copyright (C) 2012 RAC. Todos os direitos, até mesmo de tradução, são reservados. É permitido citar parte de artigos sem autorização prévia, desde que seja identificada a fonte. 


\title{
Resumo
}

O propósito do estudo foi investigar a percepção de alunos de MBA acerca do processo de aprendizagem gerencial. Foi realizado um trabalho de natureza exploratória e qualitativa com 160 alunos de 6 programas de MBA no Brasil, no período de 2004 a 2008. Os dados foram coletados através de questionário aplicado em atividades de grupo, o qual foi construído com objetivo de conduzir os participantes a identificarem conteúdos e experiências de aprendizagem associados ao desenvolvimento de capacidades e competências. Foi discutida a indicação de uma miríade de tecnologias pedagógicas para educadores sem que fossem considerados os conhecimentos valorizados como importantes pelos alunos. Três aspectos foram identificados como os mais relevantes na experiência de aprendizagem dos alunos de MBA: (a) abertura para explorar novos modos de interpretar o mundo; (b) desenvolvimento de capacidades específicas; e (c) desenvolvimento de competência relacional. A principal contribuição deste artigo é elucidar o engajamento ativo dos alunos nas oportunidades de aprendizagem criadas pelos educadores de MBA e os resultados alcançados no desenvolvimento de capacidades e competências. Com base nas evidências, argumenta-se que o planejamento pedagógico elaborado por educadores deve considerar os alunos de MBA como protagonistas do processo de aprendizagem gerencial.

Palavras-chave: educação gerencial; aprendizagem gerencial; competências; MBA.

\begin{abstract}
This paper explores MBA students' perceptions about their learning process and the outcomes of development of capabilities and competences. A qualitative exploratory study was conducted between 2004 and 2008 with 160 students enrolled in 6 different MBA programs in Brazil. The data were collected at group activities using a questionnaire to lead the participants to identify the contents and experiences from their MBA's that were associated with the development of capabilities and competences relevant to practice. Examining the current literature and its indications of a myriad of pedagogical approaches, we discuss the MBA educators' pedagogical planning for developing capacities and competences without considering which knowledge is valued as relevant by students. Our results identified three aspects as the most relevant in MBA students' learning experiences: (a) openness to exploit new ways of interpreting the world; (b) development of specific capabilities; and (c) development of relational competence. The main contribution of our study is to highlight the students' active engagement in the learning opportunities created by MBA educators and their outcomes. Based on the evidence, we argue that the pedagogical planning developed by educators should consider MBA students as the protagonist of their management education process.
\end{abstract}

Key words: management education; management learning; competence; MBA. 


\section{Introduction}

One of the specific issues in management education is the development of students' capabilities and competences in MBA programs. The main debate has focused on the contributions of MBA programs and their limitations in reaching declared educational proposals. The voices arising from the corporate field claim the teaching methods and strategies lack a practical view regarding real market problems. On the other hand, according to MBA students, the companies fail to establish conditions to exploit the knowledge developed in MBA programs (Antonacopoulou, 2008; Herrington, 2010; Perin, Sampaio, Becker, \& Fernandes, 2009; Ruas \& Becker, 2007).

Two approaches can be observed in the literature about the efficacy of MBA programs in developing students' capabilities and competences. Some authors criticize the design and methodologies of MBA programs, characterizing what they called their limitations regarding realworld business problems and demands. Their focus of analysis is on the contributions of MBA programs as an outcome of applied pedagogical technologies (Latham, Latham, \& White, 2004; Mintzberg, 2004). This critique of the lack of realistic approximation as a limitation of MBA programs is questioned by scholars who emphasize the complexity of the learning process (Antonacopoulou, 2006; Hay \& Hodgkinson, 2008). These studies focus on the process of learning (and its complexity) more than the outcomes of MBA programs. The crucial question pointed out by these studies is the proposition that even if the core purpose of MBA programs is to improve the students' capabilities and competences to deal with their daily work challenges, it will be necessary to not identify the pedagogical objectives of the course with companies' practical objectives (Antonacopoulou, 2009; Paes de Paula \& Rodrigues, 2006).

The debate about management education has evolved in recent years, especially because of contributions from Critical Management Education Studies (Closs \& Antonello, 2010; Cunliffe \& Linstead, 2009). However, some difficulties related to different approaches and claims are still present. The major difficulty, in our opinion, is how participants of these programs are described in many studies. Most of the time, these actors are considered to be extras in a movie, when they are actually the main characters. The main focus in the current literature is on planning ways to improve educators' teaching and pedagogical approaches. Our work highlights an implicit attribution of passivity to students facing teaching methods and educational objectives in MBA programs (Raelin, 2009). Considering the challenges faced by MBA students in their practice and willingness to learn, we argue that the students' role is a central aspect in the process of teaching and learning, especially regarding the development of capabilities and competences.

MBA students make connections between what they learn in their management education and what they do when they act as managers in the context of corporate practice. They do not necessarily make connections between syllabus and their business actions in a linear way or for every content and experience in their educational process in MBA programs. But the student is the one who can connect knowledge and business action with practical accomplishment. And, by doing so, he/she can integrate capabilities and knowledge in a competent act to his/her professional practice. Antonacopoulou (2008) calls this educational outcome as a process of mastering business action where the students' engagement and the purposes of MBA course are connected by the development of actionable knowledge. So, these aspects emphasize that the educational subjects planned by MBA educators can only be transformed into relevant knowledge by the students.

In the present study we investigate how the development of capabilities and competences in MBA programs occurs from the point of view of the student, who is considered the protagonist in this process. The word protagonist is being used to characterize the educational process of children, adolescents and young people in a way that they are considered as the main actor. Being the main actor, he/she experiences some opportunities to develop their personal and social identities (Souza, Finkler, Dell'agio, \& Koller, 2010). So, a protagonist is the subject that builds his/her knowledge by human action, using his/her capacity to choose and decide given a certain circumstance or context. 
MBA students are adults responsible for management process at work. Being so, we argue that he/she acts as a protagonist when he/she thinks reflexively or critically and chooses specific strategies to cope with his/her practical accomplishments at work, likewise when he/she combines contents and capacities to deal with activities proposed by educators in the context of MBA programs. At work or in an educational environment, MBA students can act as protagonists by building relevant knowledge to cope with the challenges they face.

Based on this, we asked: which aspects of management education developed during the process of learning in a MBA course are perceived as having significant value by the students? Our objective is to understand what aspects of educational experience in their process of learning through the MBA course are perceived by the students-managers as valuable and which outcomes of this process were relevant for them. Being the link between the educational and the corporate contexts, we consider the students' perceptions of relevant aspects in their educational process a very important subject in the theoretical field of management education. This perspective enhances our comprehension about the students' learning process and their outcomes regarding the development of capabilities and competences in MBA programs. Although we are not verifying these outcomes in the context of professional practice, putting our research lens on students' perceptions allow us to understand the contributions of MBA programs to their daily challenges.

To develop this reasoning, we start by analyzing the current theories on management education, emphasizing the debates on contributions of MBA programs to address questions about the development of capabilities and competences and the findings in this field. Methods and results are described to support our discussion and final comments about what is perceived as having value in MBA programs and how this understanding helps us to advance theoretically in this field.

\section{Current Theories on Management Education}

Management education in MBA programs is a frequent topic in the literature dealing with the perspective of corporate performance and the research into its relationship with some important aspects of competitive advantage, such as competences, leadership, differentiation, etc. As learning processes are considered to be one of the strategic bases for company effectiveness (Sanchez \& Heene, 2004), MBA programs are highly valued by companies and managers because they are perceived as a space to enhance managers' business practices and prepare them to deal with the environment of uncertainty and rapid changes in the current socioeconomic context. However, the main debate about the contributions of MBA programs has focused on identifying their limitations in developing management capabilities and competences that are relevant to business practice. The focus of such critiques is concentrated in two contexts of analyses: (a) companies, as the environment of business actions, where the students play the role of managers, and (b) management education programs, as the environment where strategies and methodologies aim to provide a relevant contribution to the students' professional practice in the companies. Authors address questions about the adequacy of MBA programs regarding their contribution to students' development in a way that prepares them to deal with the speed of a changing business environment, where the effectiveness of corporate performance is linked to new, increasingly complex, and superior competition and cooperation methods.

Ruas and Becker (2007) argue that specialized competences publicized in the portfolios of MBA program are not the same as those that are actually valued and sought after by MBA students in their educational process and business actions. Also, students often talk about the difficulties in applying the specialized knowledge acquired during their educational journey to their management practice when they are dealing with serendipity, uncertainty, and new challenges. If the impact of MBA programs is evaluated by the transferability of syllabi into the workplace and this, in turn, attracts companies to invest in the education of their managers as a way to obtain better results, how can we explain the existence of difficulties in transferring the management capabilities and competences developed in an 
MBA into professional practices? Actually, it is an important question that highlights the complexity of this subject and opens the way for the investigation of the claim for a more realistic connection between MBA program objectives and companies' corporate strategies. Two perspectives emerge from the literature that deals with this theme.

The first perspective emphasizes a realistic approximation with corporate strategies by reformulating the design of MBA programs and their pedagogical strategies to improve a positive influence on management practice and, consequently, to enhance corporate performance. According to this approach, Latham, Latham, and White (2004), question the lack of clarity the educational process of MBA programs has in showing students what effectiveness of results means. They complain that the lack of an integrated vision connecting management education to corporate strategy and argue that the knowledge acquired in MBA programs should prepare managers to enhance their business actions to increase the company core competences. They claim that management education programs which were designed for corporate needs, such as MBA In-company, are a more useful and strategic option than generic MBA courses.

The critiques point out that this instrumental view assumes the proposition that outcomes of MBA programs should be directly associated with results of manager performance on company performance. Even considering the role of the MBA pedagogical strategies to enhance the professional practice and business actions, what the students do when they manage is related to multiple factors and dimensions, such as power relations, micro-level process and activities in company strategy creation, etc. (Antonacopoulou, 2006; Regnér, 2003). Raelin (2009, p. 401) describes the educational context that could enhance managers business actions as a "dynamic social process - the actors, actions and interactions, activities, structures, language and other cultural artifacts - through which learning can be elicited". Any MBA curricula or syllabus could be directly or linearly associated with the very moment of the managers' business action, when students are managing and deciding what has to be done in a specific business context. Thus, what should be the proposal of MBA programs regarding its challenges in enhancing students' business actions?

The second perspective focuses on the complexity of learning, in opposition to the tendency of simplification of the educational process, so that it can be designed to deliver predetermined outcomes. Stressing the complexity, authors argue that the outcomes of the MBA programs have to be connected with the mastering of business actions by supporting effective, responsible and accountable practices (Antonacopoulou, 2009; Antonello \& Ruas, 2005; Cunliffe, 2009; Paes de Paula \& Rodrigues, 2006). This proposition puts in the center of the debate the relationship between pedagogical practices and the implications for learning. Whether approached using a critical theory or a reflective theory lens, Antonacopoulou $(2008$, p. 282) points out that "this marked an important repositioning of the relationship between learning and knowledge". The complexity perspective argues that an important subject regarding management education is the way it has been affected by globalization and the current socioeconomic scenario, especially in answering the "needs for new kinds of management capabilities which can be learned" (Antonacopoulou, 2008, p. 281).

Management leadership capabilities are characterized by Conger (2004) as an outgoing dilemma experienced by managers for being flexible and, at the same time, complying with the company's vision. This scenario, although it may seem attractive due to the opportunity of creating new practices, leads to issues that are difficult for managers to articulate when they have to deal with different interests and a growing number of external partnerships and relationships. Sanchez and Heene (2004) described managers' actions as central to the strategic results of a company. These actions require a set of complex management competences to meet corporate demands of competitiveness. Managers must constantly rethink their production methods and knowledge application to respond quickly and successfully to the challenges of the market. To Sanchez and Heene (2004) the complexity of the manager's role is related to the promotion of flexibility by continuously developing successful alternatives.

It should be noted that not all business actions attempted by managers reach their original proposal, although each new experience and exploitation represents an opportunity for learning. This 
is an important subject of the educational process in MBA programs and their pedagogical proposals, especially because it places learning in the context of students experiences and allows educators to build opportunities to critically rethink business best practices and exploit new ways of thinking (Antonacopoulou, 2009; Paes de Paula \& Rodrigues, 2006; Raelin, 2009).

The critiques regarding MBA programs in both perspectives address different views about the role of students when they act as managers and about the way pedagogical methodologies and strategies should be elaborated in the educational context. The diversity of recommendations highlights the effort made by authors to improve the educational process, to investigate the contributions of the syllabus to students' practices and to implement more relevant, accountable and strategic management education programs. Despite the theoretical advances in this field, Raelin (2009) severely criticizes the methodological choice of MBA educators when they conduct their educational practices, as they consider themselves the only source of knowledge and assume an underlying theory of students' passivity. The author demonstrates a prevalence of standardized educational practices using traditional and isomorphic pedagogical approaches in management education over the past forty years in the U.S. His proposal for changes advocates the use of a reflexive methodology based on active learning strategies, exposing students to less controlled but more realistic experiences in comparison with simulations or case studies.

Although Raelin (2009) perceives students as active actors in the learning process, the transformation in the educational process is not simple. Paes de Paula and Rodrigues (2006) demonstrate students' discomfort with alternative approaches, such as critical pedagogy. In their experience, introducing a critical approach to undergraduate students in a business school causes students' resistance in dealing with contents and activities which do not inform them of the best practices or recommended instrumental techniques. Indeed, Silva (2001) and Vieira (2005) already discuss the complexity and implications in trying to transform the instrumental reasoning by an effort towards changing pedagogical principles, educational approaches, learning purposes, and modes of teaching adopted from the educators.

The literature from theories on management education leads us to think that an important factor that deserves to be examined more deeply is the student's role in the MBA educational process. Studies in this area have focused mostly on continuous and experiential learning, emphasizing the students'/managers' analytical capacity as an ability that makes sense of uncertainties or conflict situations. Reflection, integrative thinking, integrative sense making, ways of thinking, are some of the terms used by some authors with the same theoretical goal: to explain the cognitive process of learning (Latham et al., 2004; Roglio \& Light, 2009). Even agreeing with the proposition of continuous learning as a process based on the students'/managers' experiences and reflective thoughts, these theories are not sufficient for explaining how some contents are integrated into the learning process to allow for the development of specific capabilities and competences.

Some questions that are still missing from the theoretical field of the area emerge as important in this context, such as: because the information obtained by the students in MBA programs needs to be transformed into knowledge, how does a student/manager acquire and make sense of the contents of MBA programs? How does a learning experience become meaningful in the sense of connecting the student's experiences with his/her experience as a manager? There is a lack of studies which consider the students/managers as protagonists, whose active role is considered essential for their development in the context of management education. As the theme of development of capabilities and competences underpins the discussion presented in this paper, we will analyze their current theories and findings regarding the educational process in MBA programs. 


\section{Current Theories on Capabilities and Competences}

Capabilities and competences are concepts widely used to explain how to create and develop future resources in highly dynamic markets. However, both terms can have different interpretations in literature and need to be defined to support the discussion we intend to develop. The concept of capability emerged from the early investigations of the philosophers Francis Bacon and Rene Descartes on human aptitudes for making mistakes and for the truth. Capability, in its origin, resembled the notion of aptitude, because it was defined as a capacity which provides the power to accomplish certain things. Since the studies of John Locke (1690), the concept of capability has been related to the topics of knowledge and information in philosophy. In the area of management, capability was used to explain how learning processes produce competitive advantages through the creation and application of knowledge in companies (Merbach-Müller, 2005). Three different concepts can be related to the notion of capability: (a) as a stock of knowledge, skills, and attitudes; (b) as dynamic capabilities; and (c) as potentially available resources in a given context.

The literature usually considers capability as a synonym for a set of skills, knowledge, and attitudes. It is the idea of a repertoire of strategic resources of the company that can be combined in a flexible manner. Ruas, Ghedine, Becker, Dutra and Dias (2006) argue that the problem with this concept is the underlying perspective of describing a certain group of more predictable characteristics. When it is understood as repertoire, the notion of capabilities helps to discriminate more functional profiles for selection or performance assessment processes, but it does not allow for the investigation of how the learning processes and knowledge production work to transform intangible resources into competences.

The concept of dynamic capabilities was coined by Teece, Pisano and Schuen (1997) to explain how companies' intangible assets can build capacities to respond to dynamic economic environments. The authors defined dynamic capabilities "as the firm's ability to integrate, build and reconfigure internal or external competences to approach rapidly changing environments" (p. 516). Ferdinand, Graça, Antonacopoulou and Easterby-Smith (2005) emphasized the importance of this concept for articulating the learning process in an unpredictable scenario but questioned its impact on long term competences, as such capabilities are developed only in response to immediate demands.

The third approach involves the idea of potential, which is the basis for a set of possible actions by means of combinations. The flexible and resilient nature of capabilities is emphasized by Ruas (2005) as its most important aspect. He argues that the basis of competences in their multiple forms is the integration of different capabilities that can be mobilized anytime in unexpected daily situations. The author uses the notion of event (Zarifian, 2001) to denote incidents that are part of the normal life of the company, but that, at the same time, are a result of continuous learning. An event, then, characterizes the nature of the situation while capabilities are developed through the experience of coping with daily problems and can be integrated into news capabilities or competences. Within this context, actions can be mobilized as competences to cope with the need for additional change or innovation.

The heterogeneity of the concept of capabilities is essentially based on its different levels of analyses. Although the concept of dynamic capabilities works with the organizational level, the idea of capabilities as a stock focuses on the individual level. On other hand, the notion of capabilities presented by Ruas (2005) allows for the distinction between capabilities and competences by his emphasis on the links built during the process of continuous learning in dynamic environments. In this sense, potential capabilities resources are available to use when the organization or the professional is affected by an event. The combinations of these capabilities that result in specific competences in response to an event depend on their development by continuous learning, at individual, collective, and organizational levels. We consider that this notion of capability allows characterizing MBA programs as an important educational context to create learning opportunities in which students can obtain both knowledge and capabilities to deal with challenges and events. 
The concept of competence emerged in the literature within the context of productive restructuring, which intensified new ways of understanding and organizing work due to the growing instability and low predictability in the economy and, at the same time, because of the need to improve performance levels (Boyatzis, 1982; McClelland, 1973; Parry, 1988). Generally speaking, the notion of competences denotes an action which combines capabilities and tangible resources within a specific context. An action is deemed competent when its outcome is recognized as effective (Boterf, 1995). The set of mobilized capabilities are integrated into a competence when the effectiveness of the action shows socially legitimated results as appropriate to that context and to the specific situation (Zarifian, 2001).

Competence is a heterogeneous concept, whose several different perspectives have been demonstrated by Ruas et al. (2006). The authors argued that investigations are conducted at different levels of analysis, whose contributions could be briefly characterized as:

Studies on corporate competences that emphasize survival capabilities, differentiation, or for extraordinary performance that allows for evaluation of the contribution level of a competence for the company's competitiveness (Prahalad \& Hamel, 1990).

Studies on collective competences, inserted in the set of research on corporate competences, which are the analysis of adhesion to the strategic concept of competence in work practices (Retour, Picq, Defélix, \& Ruas, 2011; Sandberg \& Torgama, 2007).

Investigations in the field of personal competences, focusing on the theme of capability development of the individual responsible for the action in his/her practice and learning processes (Boterf, 1995; Dutra, 2001; Zarifian, 2001).

Analysis of professional or management competences aimed at studying the action in which individual and collective capabilities are mobilized in the social practice situated on everyday events, in the particular context of a workplace and business (Antonacopoulou \& Chiva, 2007; Antonello \& Ruas, 2005).

On the specific topic of professional competence, Sandberg and Pinnington (2009) analyzed the daily activity of lawyers at an international corporate law firm to investigate how different aspects of work practice are integrated into specific competences. The authors suggest that the diversity of theories relating competence to action-oriented capabilities contributes to the investigation of two topics: (a) the relational nature of competence, especially the theoretical perspectives of action-based, understanding of work, and practice as the locus of competence; and (b) the importance of achieving a corpus of scientific and tacit knowledge, in particular regarding the benchmarks of knowledge management, tacit dimensions of professional competence, and the aforementioned perspective of competence as an inventory of knowledge, skills, and attitudes. However, they argue that such contributions do not elucidate how specific professional competences are integrated into practice.

Sandberg and Pinnington (2009) claim that professional competences are not primarily constituted by knowledge or skills; instead, they are developed by how the professional sees his/her work and defines certain attributes as capabilities, arranging them into specific competences. The authors assume that competence is socially developed because the particular manner of how a professional engages in action defines his/her ways of practicing. Competence, thus, is defined as something that we are and we do in relation to others, and with useful tools for our performance. According to this point of view, the educational process of professionals is incremental as they develop students-managers through the transformation of their ways of seeing the world. Changes in the modes of professional practice occur through the integration of capabilities into different and gradually more complex patterns of professional competences in the context of business actions.

Ruas (2010) demonstrates that the development of students' competences in MBA programs should not to be seen as a simple transmission of specialized knowledge through a disciplinary approach. In his research, few students in Brazilian MBA programs identified insights associating competences as a practical experience in their workplace with the contents studied in the program. The 
author points out an important element in this discussion: a capability developed in a previous experience will not always be enough to deal with similar or more complex situations. It means that a set of students' knowledge and capabilities learned previously has the potential to be articulated in a competent act when they are managing. The combination of knowledge, capabilities and competences is only possible regarding what they had learned, but there are no guarantees that they are prepared to deal successful with all events or every business contexts.

About the process of management learning, Antonacopoulou and Chiva (2007) state that one must consider: (a) the students' effort to be recognized as a professional in the corporate culture where they work; and (b) the tensions between an individual's learning purposes and corporate learning priorities which affect the motivation to learn. The authors emphasize that the learning context shapes learning opportunities and also characterizes the students'-managers' learning processes as a practical accomplishment placed on a socio-political dynamic that underlies and defines their educational purposes at the individual level. The process of learning contents, capabilities and competences enables the students to improve ways of acting that shape their business practices. However, the practical accomplishment requires a conscious exercise of their practical judgment in the action they take in response to problematic situations. Also, it requires an understanding of the social forces shaping the feasibility of new ways of practicing (Antonacopoulou, 2009; Warhurst, 2011).

The main question proposed by these authors is that previously learned capabilities and knowledge are not instrumental prescriptions, but they do help MBA students to better deal with their daily challenges. Developing capabilities and competences requires a twofold engagement from the students. An engagement in the process of rethinking their practice in rebuilding business action is necessary, which could be legitimated as competent acts (Antonacopoulou \& Chiva, 2007; Ruas, 2010). These findings highlight the importance of devoting more attention to the student as a protagonist of this process of learning. At the same time, they open the way to rethink the role of management education programs to create learning opportunities that move away from ready-made solutions which place the students as a passive consumer of magic solutions to be replicated unreflectively (Paes de Paula \& Rodrigues, 2006).

\section{Method}

A qualitative exploratory study was conducted between 2004 and 2008 with students enrolled in six different MBA programs in Brazil. The participants were 160 MBA students, $60 \%$ of whom were male. Their age ranged from 28 to 50 years ( $M=32$ years). They were all employed in public and private organizations as executive managers, managers, and technical managers. The MBA programs were among the top 10 management education programs in the country. In order to select MBA programs we used a twofold criterion: (a) institutions located in different cities with different programs and methods; (b) part-time programs where students alternated educational activities and management practice.

\section{Data collection}

Data collection was carried out by one of the authors of this study who conducted a Workshop of Management Competences and Learning as one of the final activities at each MBA program researched. Each Workshop included 20 to 28 students from each MBA program. The goal of the workshop was to engage the students-managers in a reflexive practice to collect data about their perceptions on the educational process and its outcomes. Meetings were carried out for a period of 12 to 16 hours on two consecutive days. The activities were organized as follows:

1. Building common references: Before the activities in the Workshop, two papers dealing with management learning and development of capabilities and competences were discussed. These papers were sent to the participants in advance. The presentation of the concepts of capability, 
competences and management learning and the later discussion were activities employed to build a shared conceptual framework among the students. The main purpose was establishing a common reference for the activities that happened afterwards.

2. Stage of individual reflection: Each participant received a standardized instrument, mixing qualitative and objective questions, with four sections. The order of the sections was designed to allow the description of subjects and experiences, characterized as significant to the students' process of learning in the MBA course, and to achieve an identification of capabilities and competences that were perceived as a relevant outcome for their professional practice. Sections were organized in the following mode:

- Recall each of disciplines which the MBA students attended in the program to stimulate them to remember learning subjects and experiences which were significant.

- Identification of the 10 main subjects and experiences in the program, considering their importance regarding professional work demands. This activity was designed to stimulate students to associate subjects and experiences with their process of learning in the MBA context. Examples of subjects pointed out by students in this section were systemic view, organizational culture, creativity and innovation. Instances of experiences were preparation of a group seminar during the MBA and technical visits to different companies.

- Selection of the four most important subjects and experiences for their practical activities among the 10 previously identified by them.

- Association of each subject and experience with capabilities and competences regarding their practical accomplishment at work. Students were to associate these categories with their process of learning and the outcomes valued by them.

3. Stage of small group reflection: Once the individual activity was completed, each student had to keep his/her questionnaire filled and join in a small group of 5 to 6 participants. The task of the small group was to build collective answers about the 4 most important subjects and experiences, and also about the identification of capabilities and competences associated with their process of learning in the MBA program. To create a collective comprehension about these subjects, the group should: share their individual answers from sections 3 and 4, discuss the individual meanings, and, finally, produce a collective definition about which aspects of management learning were the four most important for them regarding subjects and experiences (section 3) and capabilities and competences (section 4).

4. Stage of large group reflection: The final step of the data collection was to return to the large group with the aim of obtaining a description of the subjects, experiences, capabilities and competences which they considered as the most relevant. Each small group presented its conclusions to the other groups to reach a collective set of subjects, experiences, capabilities and competences that represented the students' educational process at the MBA program. While they were debating, the researcher who conducted the Workshop introduced questions like: "why is subject $\mathrm{X}$ more important than subject Y?" or "which capabilities (or competences) were relevant to your management activity?" The questions were selected with the objective of solving the researchers' interpretational doubts, providing assistance so the participants could develop their descriptions, and offer concrete examples of activities or interpretations. An example of the associations produced by the participants can be seen in Table 1. 
Table 1

\section{Example of the Categories Given by One Small Group}

\begin{tabular}{llll}
\hline Subjects & Experience & Capabilities & Competence \\
\hline $\begin{array}{l}\text { Internationalization of } \\
\text { Brazilian Economy }\end{array}$ & $\begin{array}{l}\text { Discussion of conflictive } \\
\text { perceptions about the } \\
\text { main topics to be } \\
\text { prepared as a presentation } \\
\text { in a seminar }\end{array}$ & $\begin{array}{l}\text { Exploration of different } \\
\text { perspectives and ideas }\end{array}$ & $\begin{array}{l}\text { Interactions with } \\
\text { colleagues who are more } \\
\text { experienced }\end{array}$ \\
Organizational culture & $\begin{array}{l}\text { Associating and } \\
\text { analyzing distinct } \\
\text { suggestions }\end{array}$ & \\
$\begin{array}{l}\text { Organizational } \\
\text { learning }\end{array}$ & $\begin{array}{l}\text { Be capable to listen and } \\
\text { understand other ways of } \\
\text { doing things }\end{array}$ & \\
& & & \\
\hline
\end{tabular}

Source: elaborated by the authors.

\section{Data analysis}

Data analyses were conducted with the collective answers obtained in the small groups. Therefore, only sections 3 and 4 were analyzed in the present study. The answers that emerged from the MBA students of the 6 programs researched were systematized into categories that were identified as main themes. For each MBA program 96 answers were collected regarding subjects (24), experiences (24), capabilities (24) and competences (24). The categories were grouped using a content analysis technique (Strauss \& Corbin, 2009).

A key factor to this study was to gather a class of MBA students to reflect on their educational practice regarding some specific aspects (subjects and experiences) and outcomes (perception of capabilities and competences developed). A common reference for the capabilities and competences concepts about the process of learning was crucial to the reliability of the data collected. Public group discussions allowed us to collect representative data from the students' perceptions of their MBA programs. This approach, based on a communication technique, helped validate the researchers' analysis, striving for coherent interpretation (Sandberg, 2005). Another important aspect to ensure the validity of the data obtained was the follow-up questions applied during the Workshop. As Sandberg (2005, p. 56) demonstrate, "one way to achieve pragmatic validity when generating descriptions of lived experienced is to ask follow-up questions that constantly embed the statements in concrete situations". This strategy enhanced the students' ability to assess what they considered to be relevant for their practice, avoiding researcher bias.

\section{Results}

To investigate aspects of management education in MBA programs according to the students' point of view produced empirical evidence about their process of learning and its contributions to professional development. The results were grouped into three categories of perceived value by students-managers. These categories represent the most significant subjects and experiences that they connected with the capabilities and competences considered relevant for shaping their business actions. Based on the empirical evidence, three aspects of management education were identified from the MBA students' perspective: (a) openness to exploit new ways of interpreting the world; (b) development of capabilities; and (c) development of relational competence. Table 2 summarize these findings. 
Openness to exploit new ways of interpreting the world was the most valued experience to enhance their practical accomplishment dealing with daily situations and new challenges. Studentsmanagers felt that transforming their ways of interpreting is the most evident aspect of integration between the knowledge learned and flexible strategic capabilities. In the educational contexts, they can problematize phenomena of business practice which they previously didn't realize or which they were overestimating or simply ignoring as important to their practical accomplishment. The students highlighted the openness to exploiting new ways to interpret things, people, resources and the society as the first step to bind contents and experiences lived in the educational process with new business actions.

The second aspect most valued in the educational process was the development of some capabilities identified as a mastering of students' practical accomplishment. They pointed out three capabilities: (a) an analytical and associative capability; (b) a reflective capability; and (c) a capability to tolerate differences. The analytical and associative capability is characterized by MBA students as a cognitive dimension that allows reflecting upon strategic aspects of business practices. As managers, they have to constantly analyze and associate information. Thus, they valued the opportunity to think beyond their current demands, and also the possibility to be in touch with specialized knowledge and instances of different contexts of business practices. An example was the influence of subjects that they learned in an educational activity conducted to make them rethink practices on business internationalization. MBA students were compelled to analyze scenarios and information and then to associate their contents with business actions found in both individual and group tasks. Applying theoretical references in that activity helped them to enrich analytical capacity by associating ideas and concepts with specific business actions. As they want to combine what they learned in the MBA educational context with their professional practice, this capability was one the most valued to master their business actions.

Another highly valued capability was the reflection upon practices in a way that led them to see beyond routines and to change their own interpretation of business actions. This was not described as a process of cognitive learning just used to adapt one instrumental business tool or some best practice they learned. The MBA students-managers felt that some of the educational subjects and experiences in learning contexts encouraged them to reflect on important issues in business practices, professional actions and other aspects that they had not looked at carefully before. An instance of this topic was the students' capacity of learning from their own mistakes and discoveries in the MBA educational context. They interpreted the exploitation of ideas and knowledge as an opportunity of learning that enables the creative expansion of their thinking, which is feasible in the business context where there should be no mistakes.

More than analyzing and associating contents to improve their business practices, the reflective capability is considered as a potential bridge between capabilities learned in the MBA educational process and the real problems faced by students when they manage. To reflect on their daily practices, mistakes and discoveries were considered a relevant learning outcome that helps students when they are at the very moment of decision-making. This process underlies the way that students make sense of knowledge regarding what they consider relevant to their practical accomplishment. To read a report, or to listen to teamwork complaints, were related as acts which gained new meanings when students began questioning their usual understanding of acts, data, people, business and society.

The last capability evidenced was the tolerance of differences. MBA students are constantly forced to negotiate with colleagues in research activities, seminars, group works, and other pedagogical tasks. This aspect was mentioned as important for providing the opportunity to learn how to be tolerant to listen to different points of view, confrontations, or discrepant interpretations. As enhancing capacity to listen is the basis for tolerance of differences, it is important to develop these capabilities in MBA students who have to deal with challenges at business partnerships and relationships with team works, boarders, stakeholders and shareholders.

Finally, the third aspect evidenced in this research is that the only and most important contribution of MBA programs regarding competences was as an enhancement of MBA students' 
interpersonal behavior. They valued this competence developed as an improvement of interactive business actions which are relevant to their professional practice, such as negotiating and networking.

Table 2

Aspects of Management Education Valued by Students-managers

\begin{tabular}{|c|c|c|}
\hline \multicolumn{3}{|c|}{ Aspects of learning process related } \\
\hline Experience & $\begin{array}{l}\text { Openness to explore new ways of } \\
\text { interpreting the world }\end{array}$ & $\begin{array}{l}\text { Being enabled to questioning and } \\
\text { exploring multiple aspects and } \\
\text { dimensions of business practices. }\end{array}$ \\
\hline \multirow{3}{*}{ Capabilities } & Analytical and associative capability & $\begin{array}{l}\text { Thinking beyond demands of daily } \\
\text { routines and learning about } \\
\text { specialized knowledge in similar } \\
\text { and different contexts of business } \\
\text { practices. }\end{array}$ \\
\hline & Reflective capability & $\begin{array}{l}\text { Building meanings that can bind } \\
\text { knowledge and capabilities learned } \\
\text { with the challenges faced in the } \\
\text { workplace. }\end{array}$ \\
\hline & Capability to tolerate differences & $\begin{array}{l}\text { Being enabled to listen to } \\
\text { confrontations or distinctive } \\
\text { positioning and actually think about } \\
\text { their relevance. }\end{array}$ \\
\hline Competence & Relational competence & $\begin{array}{l}\text { Enhancing relationships and } \\
\text { partnerships that improve interactive } \\
\text { business actions. }\end{array}$ \\
\hline
\end{tabular}

Source: elaborated by the authors.

\section{Discussion}

Two issues of management education in MBA programs stand out. First, focusing on the students' perspective, enhance our understanding about the educational aspects that were significant and relevant for them. Our findings evidence their active engagement in performing their role as students to achieve specialized knowledge, flexible capabilities and specific competences. In a myriad of pedagogical technologies, MBA educators' purposes, educational priorities of their company, educational proposal of MBA programs, among others, MBA students embrace some subjects and experiences that have the potential to help them deal with demands and challenges. Thus, the learning outcome most valued by them is to be enabled in combining experiences of openness to explore alternatives with capabilities and competences relevant to their practice.

Our results help to integrate some findings pointed out in the literature. Sandberg and Pinnington (2009) argue for transforming managers' ways of seeing things in educational context by considering other possibilities of interpreting world. However, just becoming aware of alternatives is not enough to rethink practices or to develop capabilities and competences (Paes de Paula \& Rodrigues, 2006; Ruas, 2010). From the students' point of view, as we demonstrated, the aspect valued by them is the combination of new ways of interpreting the world with new ways of thinking. In another perspective, Mintzberg and Gosling (2003), Latham et al. (2004), and Roglio and Light (2009) state the importance of developing analytical and associative capabilities such as reflective thinking and integrative sense making. This position is contested by Paes de Paula and Rodrigues (2006), Antonacopoulou $(2008,2009)$, and Ruas (2010) who claim that just reasoning and comparisons are not 
sufficient for achieving significant knowledge. MBA students in our study pointed out that connecting knowledge and capabilities to handle more complex situations is a continuous learning process that bind MBA educational context with challenges faced by them at workplace. So, the key aspect valued by MBA students is the integration of an analytical-associative capability with a reflective capability that enhances learning and allows them to exploit mistakes and discoveries in the MBA educational context.

Our findings about the capability to tolerate difference and relational competences align with those of Ruas (2005) and Antonacopoulou and Chiva (2007). The sociopolitical and complex nature of a learning process is evidenced by the way that the MBA educational context, company priorities, and relationships shape learning opportunities and educational purposes in MBA students.

More than an integrative approach, our findings highlight that the learning process depends on the students' effort to glimpse alternative interpretations (openness), to think beyond the demands of daily routines (analysis and association), to achieve new meanings for their practice (reflection), to listen to confrontations and distinctive reasoning (tolerate differences), and to enhance their interactions (relational competences). The results suggest that MBA students' engagement in the learning process triggers the learning outcomes that they can achieve. Its aspect is especially observed in MBA students evaluations of subjects/experiences and capabilities/competences in our research. Their engagement analyzing the influence of learning experiences at MBA context demonstrates they are willing to lean about their own process of learning. It highlighted the impact of educational processes developing professional identity and improving business actions. Therefore, we argue that the students' educational purpose is a key factor that underlies which aspects they will engage to learn, even when they do not immediately see an instrumental application of the specialized knowledge that is being taught. Enhancing our understanding of what MBA students value allows us to observe their engagement with significant experiences in which they can act or learn to act as protagonists in their educational process.

The second issue that we want to address in this paper concerns the development of students' competences in the MBA educational contexts. Usually, MBA programs are considered as an educational context designed to develop competences (Perin et al., 2009). To the contrary of this argumentation, our results demonstrate that MBA students' learning is more intensively achieved for developing capabilities than competences. The evidence of continuous learning in MBA programs shows that even when the students-managers do not develop specific competences at a given moment, the capabilities are the most dynamic and potential basis of competences. Supported by such evidence, we build our theoretical perspective based on a conceptual framework which highlights the role of continuous learning in development of capabilities and competences, as showed in Figure 1.

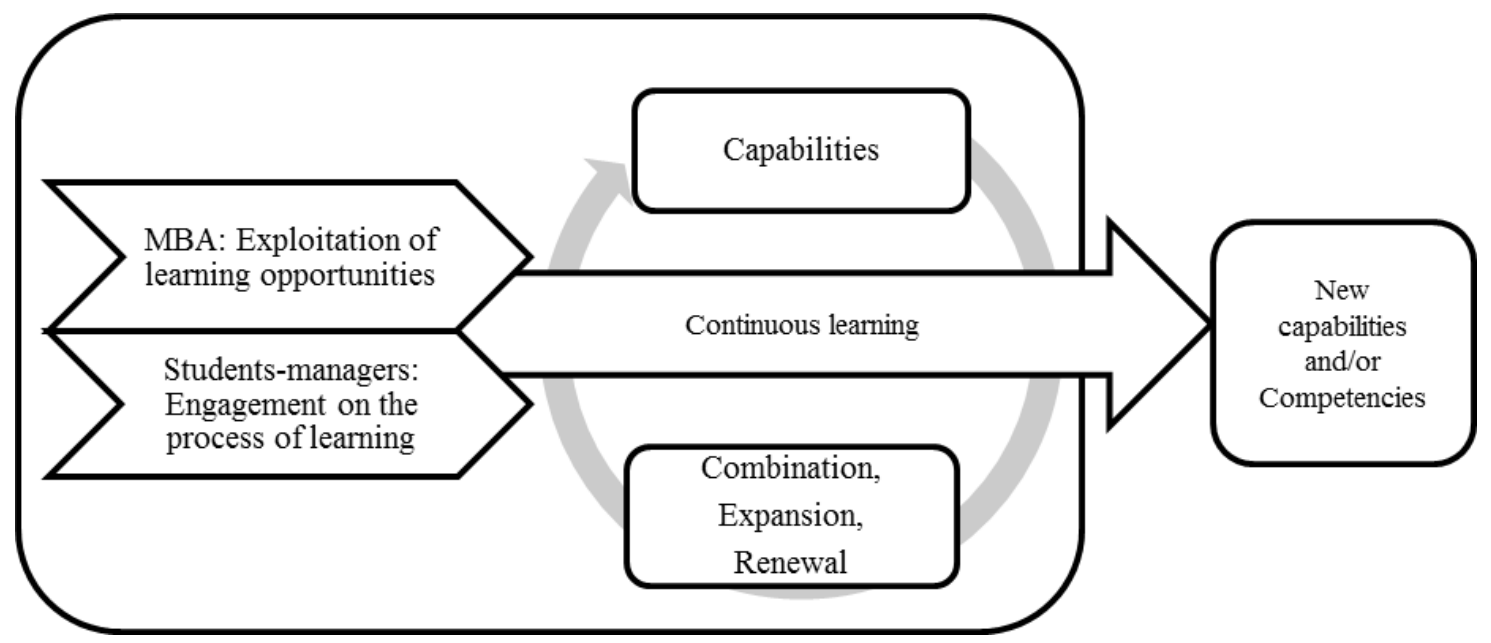

Figure 1. Conceptual Framework of the Learning Process in MBA Educational Context. Source: elaborated by the authors. 
We argue that the MBA's main contribution is related to exploration of learning opportunities by the students. In the educational context, MBA students can try different roles, react to different situations, and observe their own improvement by integrating syllabi into flexible capabilities and competences. The key factor for engaging students-managers in processes of combination, expansion and renewal of capabilities lies in the impact of their ways of interpreting world. Actually, the specificity of competences developed by the MBA students seems to be based in the flexible and resilient nature of capabilities. Based on this perspective, we argue that the authors' treatment of the issue of educational proposal of MBA programs should consider the students' role. Surprisingly, the linkage between management education and management practice is described in literature as a movement produced by MBA educators through appropriate pedagogical technologies (Mintzberg \& Gosling, 2003; Raelin, 2009). However, how would it be possible for MBA educators to articulate methodologies and techniques in a relevant way without examining what students value?

A myriad of pedagogical technologies presented in the literature are just instruments to build learning opportunities, the necessary context for developing capabilities and competences. MBA educators should re-analyze the role of pedagogical technologies facing MBA students' expectations, their challenges and practical accomplishments. In the literature on adult pedagogies, some authors emphasize as a central principle the exploitation of apprentices' experiences in fostering autonomy, initiative and creativity. This approach points out pedagogical procedures which trigger specialized knowledge from students' experiences with educational activities such as collaborative projects, works groups, empirical and theoretical research and collective reflection about new solutions for current problems (Meignant, 2006; Mucchielli, 2008; Santelmann, 2004). Thus, we argue that every technique and instrument needs to be contextualized and bounded in a way that it can become a significant experience for students. To create significant meanings for MBA students, the educational focus should not rely only on pedagogical technologies. It should be planned by MBA educators as learning opportunities that shape certain circumstances, promote collaborative experiences with colleagues and exploit capabilities linked to the knowledge taught. In that sense, MBA educators should be attentive to the social, situated and political aspects in the learning process, and also consider MBA students' backgrounds and professional histories.

However, MBA educators end up assigning a condition of passivity to students in the learning process because they disregard students' role in the process of learning. We argue that they should connect their pedagogical proposals with management practice by engaging MBA students in subjects and experiences potentially relevant to them. Thus, the pedagogical planning developed by educators should consider the MBA students as responsible for their educational process; as protagonists who are the main character in their learning process. What we are reinforcing at this point is that MBA students' learning is a process of knowledge construction which is mostly influenced by the MBA context and professors when educational strategies consider what is relevant for practical accomplishment.

To consider what is relevant to MBA students, MBA educators have to reposition their way of planning, teaching and acting as professors, re-thinking their practices and the passivity attributed to students. Driving their pedagogical objectives and activities to take into account MBA students as protagonists is our main proposal in this paper. We also point out the enrichment of learning opportunities in MBA contexts through exploitation of new combinations of knowledge and action which have the potential to emerge as relevant to professional practice of MBA students. To accomplish this, some questions need to be considered for the MBA educational contexts: which kinds of learning opportunities are being created? Are subjects and learning experiences influencing students' ways of interpreting the world? Are capabilities being mobilized by the events created by educators at MBA program also taking advantage of students' mistakes and discoveries? Which aspects of pedagogical activities are provoking the engagement of MBA students in the process of learning? 


\section{Final Comments}

Our results show that the main contribution of the present study is to highlight MBA students' role as protagonists of their learning process and its outcomes. Two main aspects stand out in this paper: students' active engagement and the learning opportunities provided by MBA educators. We claim that the strength of MBA programs lies exactly in their context of opportunities to support experiences in which MBA students can combine knowledge, capabilities and competences to deal with their daily challenges at work. The way that MBA students rethink practices depends on their active responses to the subjects and experiences faced in MBA educational contexts. Thus, it is essential to include the students' perspective in order to analyze the impact of educational practices in the MBA context. To do this, MBA students have to be seen as the protagonist in the dynamics of learning.

Our empirical evidence that focused on the aspects of management education valued by the MBA students demonstrates that the educational contexts of MBA programs tend to have a more effective impact on the development of capabilities than competences. Its findings state that learning opportunities created by MBA educators have the potential to change students' ways of being, of interpreting and of practicing and thus shape MBA students' business actions. Based on this, we argue that the impact of MBA programs should be analyzed regarding continuous learning opportunities that mobilize students' capabilities and competences; provoking them to an active engagement in the educational process. Conducting further studies in the area is a relevant factor for the discussions about management education and development of competences. Although the focus of the present study was the identification and description of management education aspects, our data provide information about the nature of the process that may be addressed in future studies.

However, because of our methodological procedures, it was not possible to analyze the influence of different pedagogical and methodological approaches in the MBA programs researched. We are stressing this aspect because our data analysis did not identify significant differences between them. Considering institutionalized practices of MBA educators (Raelin, 2009), it is important to consider this topic for future research. One aspect that could be explored in this subject is the very similar perspective in which MBA students describe their business environments and challenges. In our research, they characterized their business contexts using similar words, as uncertainties, rapid changes and dynamism. Their narratives about which competencies would be necessary to face their challenges were described which certain homogeneity and isomorphism. So, some questions can be posted here to foster future research in management education, such as: how are MBA students' learning expectations being shaped by the organizational discourse about business context and actions? To what extent are similarities in MBA students influenced by institutionalized practices of teaching and learning? These questions can enlarge our comprehension about the political and social nature of learning processes in MBA programs.

\section{Artigo recebido em 07.01.2011. Aprovado em 09.12.2011.}

\section{Acknowledgments}

This research was supported by the National Research Council (CNPq) and by CAPES (an agency of the Ministry of Education) in Brazil. We also would like to thank Professor Claudio S. Hutz for his valuable comments on an earlier draft of our manuscript. 


\section{References}

Antonacopoulou, E. (2006). The relationship between individual and organizational learning: new evidence form managerial learning practices. Management Learning, 37(4), 455-473. doi: $10.1177 / 1350507606070220$

Antonacopoulou, E. (2008). Mastering business action: Implications for management learning in business schools. In P. Martensson, M. Bild, \& K. Nilsson (Orgs.), Teaching and learning at business schools (pp. 279-295). Burlington: Gower.

Antonacopoulou, E. (2009). Impact to scholarship: unlearning and practising to co-create actionable knowledge. Management Learning, 40(4), 421-430. doi: 10.1177/1350507609336708

Antonacopoulou, E., \& Chiva, R. (2007). The social complexity of organizational learning. Management Learning, 38(3), 277-295. doi: 10.1177/1350507607079029

Antonello, C. S., \& Ruas, R. L. (2005). Formação gerencial: pós-graduação lato sensu e o papel das comunidades de prática. Revista de Administração Contemporânea, 9(2), 35-58. doi: 10.1590/S1415-65552005000200003

Boterf, G. (1995). De la competence. Paris: Les Éditions d’Organisation.

Boyatzis, R. E. (1982). The competent manager. New York: John Wiley and Sons Inc.

Closs, L. Q., \& Antonello, C. S. (2010). Aprendizagem transformadora: a reflexão crítica na formação gerencial. Cadernos EBAPE BR, 8(1), 20-37. doi: 10.1590/S1679-39512010000100003

Conger, J. (2004). Developing leadership capability: what's inside the black box. Academy of Management Executive, 18(3), 136-139.

Cunliffe, A. L. (2009). The philosopher leader: on relationalism, ethics and reflexivity - a critical perspective to teaching leadership. Management Learning, 40(1), 87-101. doi: $10.1177 / 1350507608099315$

Cunliffe, A. L., \& Linstead, S. (2009). Introduction: teaching from critical perspectives. Management Learning, 40(1), 5-9. doi: 10.1177/1350507608099310

Dutra, J. S. (2001). Competências. São Paulo: Atlas

Ferdinand, J., Graça, M., Antonacopoulou, E., \& Easterby-Smith, M. (2005). Dynamic capability [Evolution Business Knowledge working paper 2005/09]. Economic and Social Research Council, London, UK.

Hay, A., \& Hodgkinson, M. (2008). More success than meets the eye: a challenge to critiques of MBA. Possibilities for critical management education? Management Learning, 39(1), 21-40. doi: $10.1177 / 1350507607085170$

Herrington, D. (2010). MBA: past, present and future. Academy of Educational Leadership Journal, 14(1), 63-76.

Latham, G., Latham, S., \& Whyte, G. (2004). Fostering integrative thinking. Journal of Management Education, 28(1), 3-18. doi: 10.1177/1052562903252647

Locke, J. (1690). An essay concerning human understanding. London: Basset.

McClelland, D. C. (1973). Testing for competence rather than intelligence. American Psychologist, 28(1), 1-14. doi: 10.1037/h0034092 
Meignant, A. (2006). Manager la formation. Ruel-Malmaison: Liaisons.

Merbach-Müller, H. (2005). Francis Bacon's praise'. Knowledge Management Research \& Practice, 3(1), 45-46. doi: 10.1057/palgrave.kmrp.8500048

Mintzberg, H. (2004). Managers not MBAs. United Kingdom: Harlow.

Mintzberg, H., \& Gosling, J. (2003). Educando administradores além das fronteiras. Revista de Administração de Empresas, 43(2), 29-43.

Mucchielli, R. (2008). Les méthodes actives dans la pedagogie des adultes. Moulineaux : ESF Editeur.

Paes de Paula, A. P., \& Rodrigues, M. A. (2006). Pedagogia crítica no ensino da administração: desafios e possibilidades [Special Issue]. Revista de Administração de Empresas, 46, 10-22.

Parry, S. (1988). Just what is competency? Training, 35(6), 59-64.

Perin, M. G., Sampaio, C. H., Becker, G. V., \& Fernandes, B. H. R. (2009). O impacto da formação gerencial no desempenho organizacional à luz da abordagem de competências. Brazilian Business Review, 6(1), 104-120.

Prahalad, C., \& Hamel, G. (1990). The core competencies of the corporation. Harvard Business Review, 68(3), 79-91. doi: 10.1007/3-540-30763-X_14

Raelin, J. (2009). The practice turn-away: forty years of spoon-feeding in management education. Management Learning, 40(4), 401-410. doi: 10.1177/1350507609335850

Regnér, P. (2003). Strategy creation in the periphery: inductive versus deductive strategy making. Journal of Management Studies, 40(1), 57-82 . doi: 10.1111/1467-6486.t01-1-00004

Retour, D., Picq, T., Defélix,C., \& Ruas, R. L. (2011). Competências coletivas. Porto Alegre : Artmed.

Roglio, K. D., \& Light, G. (2009). Executive MBA programs. Academy of Management Learning and Education, 8(2), 156-173.

Ruas, R. L. (2005). Literatura, dramatização e formação gerencial. Organizações e Sociedade, 12(32), 121-142.

Ruas, R. L. (2010). Aprendizagem nas organizações (Research Report /2010), Brasília, DF, Conselho Nacional de Desenvolvimento Científico e Tecnológico.

Ruas, R. L., \& Becker, G. V. (2007, June). Desenvolvendo competências em programas de formação gerencial: ficção e realidade. Proceedings of the do Encontro de Gestão de Pessoas e Relações de Trabalho, Natal, RN, Brazil, 1.

Ruas, R. L., Ghedine, T., Becker, G., Dutra, J., \& Dias, G. (2006, August). The concept of competence. Proceedings of the Academy of Management Annual Meeting, Atlanta, GA, United States of America.

Sanchez, R., \& Heene, A. (2004). The new strategic management: organizations, competition and competence. New York: Wiley Hoboken.

Sandberg, J. (2005). How do we justify knowledge produced within interpretative approaches? Organizational Research Methods, 8(1), 41-68. doi: 10.1177/1094428104272000

Sandberg, J., \& Pinnington, A. (2009). Professional competence as ways of being. Journal of Management Studies, 46(7), 1138-1170. doi: 10.1111/j.1467-6486.2009.00845.x

Sandberg, J., \& Torgama, A. (2007). Managing understanding in organizations. London: Sage. 
Santelmann, P. (2004). De l'efficacité em formation continue. Ruel-Malmaison: Liaisons.

Silva, F. L. (2001). A perda da experiência da formação na universidade contemporânea. Tempo Social, 13(1), 27-37. doi: 10.1590/S0103-20702001000100003

Souza, A. P. L., Flinker, L., Dell'agio, D. D., \& Koller, S. H. (2010). Social participation and protagonism. Avances en Psicología Latinoamericana, 28(2), 178-193.

Strauss, A., \& Corbin, J. (2009). Pesquisa qualitativa. Técnicas para o desenvolvimento de teoria fundamentada. Porto Alegre: Artmed.

Teece, D. J., Pisano, G., \& Schuen, A. (1997). Dynamic capability and strategic management. Strategic Management Journal, 18(7), 509-533. doi: 10.1002/(SICI)10970266(199708)18:7<509::AID-SMJ882>3.0.CO;2-Z

Vieira, F. (2005). Transformar a pedagogia na universidade? Currículo sem Fronteiras, 5(1), 10-27.

Warhurst, R. (2011). Managers' practice and managers' learning as identity formation: reassessing the MBA contribution. Management Learning, 42(3), 261-278. doi: 10.1177/1350507610387567

Zarifian, P. (2001). Objetivo competência. São Paulo: Atlas. 